\title{
Estimate of the energy value of soybean meal relative to corn based on growth performance of nursery pigs
}

Henrique S. Cemin'1, Hayden E. Williams', Mike D. Tokach', Steve S. Dritz², Jason C. Woodworth', Joel M. DeRouchey ${ }^{1}$, Robert D. Goodband ${ }^{1 *}$ (D, Kyle F. Coble ${ }^{3}$, Brittany A. Carrender ${ }^{3}$ and Mandy J. Gerhart ${ }^{3}$

\begin{abstract}
Background: Two experiments were conducted to determine the effects of increasing amounts of soybean meal (SBM) in swine diets and estimate the energy value of SBM.

Methods: A total of 2233 pigs (PIC $337 \times 1050$, Hendersonville, TN) and 3796 pigs (PIC $359 \times$ C40), initially $11.0 \mathrm{~kg}$ and $17.6 \mathrm{~kg}$ body weight (BW), were used in Exp. 1 and 2, respectively. In Exp. 1, pigs were placed in 92 pens each containing 20 to 27 pigs. In Exp. 2, pigs were placed in 84 pens each containing 37 to 43 pigs. Treatments were assigned in a randomized complete block design with BW as the blocking factor. Dietary treatments consisted of 21\%, 27\%, 33\%, or 39\% SBM in Exp. 1 and 17.5\%, 22\%, 26.5\%, 31\%, 35.5\%, or 40\% SBM in Exp. 2, obtained by changing the inclusion rate of feed-grade amino acids and corn grain. For Exp. 1, representative samples of corn grain, SBM, and distillers dried grains with solubles were analyzed for total AA content prior to diet formulation. For Exp. 2, diets were formulated using NRC (2012) nutrient loadings. Treatment diets were fed for 21 and $22 \mathrm{~d}$ (Exp. 1 and 2) and there were 23 replicates in Exp. 1 and 14 replicates in Exp. 2. Pigs were weighed and feed disappearance measured weekly to calculate average daily gain (ADG), average daily feed intake (ADFI), gain-to-feed ratio (G:F), and caloric efficiency (CE). Data were analyzed with block as a random effect and treatment as a fixed effect, and contrasts were constructed to test the linear and quadratic effects of increasing SBM.

Results: In Exp. 1, there was a tendency (linear, $P=0.092$ ) for a decrease in ADFI as SBM increased. There was a tendency $(P=0.090)$ for a quadratic response for ADG, with a decrease in ADG observed with 39\% SBM inclusion. Pigs fed diets with increasing SBM had a tendency (quadratic, $P=0.069$ ) for an increase in G.F up to 33\% SBM and an improvement (linear, $P=0.001$; quadratic, $P=0.063$ ) in CE with increasing SBM. Using CE to estimate the energy of SBM relative to corn, a value of $105.4 \%$ of corn energy or $2816 \mathrm{kcal} / \mathrm{kg}$ NE was determined using all data points. When removing the CE value of the $39 \%$ SBM treatment due to the quadratic tendency, SBM was estimated to have $121.1 \%$ of corn energy or $3236 \mathrm{kcal} / \mathrm{kg} \mathrm{NE}$. In Exp. 2, there was a decrease (linear, $P=0.001$ ) in ADFI. Pigs fed increasing SBM had a tendency (linear, $P=0.065$ ) for reduced ADG but an improvement (linear, $P=0.001$ ) in G:F and CE as SBM increased. The energy value of SBM was estimated as $124.7 \%$ of corn energy or $3332 \mathrm{kcal} / \mathrm{kg} \mathrm{NE}$.

\footnotetext{
* Correspondence: goodband@ksu.edu

'Department of Animal Sciences and Industry, College of Agriculture, Kansas State University, Manhattan, KS 66506, USA

Full list of author information is available at the end of the article
}

C C The Author(s). 2020 Open Access This article is licensed under a Creative Commons Attribution 4.0 International License, which permits use, sharing, adaptation, distribution and reproduction in any medium or format, as long as you give appropriate credit to the original author(s) and the source, provide a link to the Creative Commons licence, and indicate if changes were made. The images or other third party material in this article are included in the article's Creative Commons licence, unless indicated otherwise in a credit line to the material. If material is not included in the article's Creative Commons licence and your intended use is not permitted by statutory regulation or exceeds the permitted use, you will need to obtain permission directly from the copyright holder. To view a copy of this licence, visit http://creativecommons.org/licenses/by/4.0/ The Creative Commons Public Domain Dedication waiver (http://creativecommons.org/publicdomain/zero/1.0/) applies to the data made available in this article, unless otherwise stated in a credit line to the data. 
(Continued from previous page)

Conclusions: The results suggest that feeding increasing levels of SBM improves G:F and CE. The energy value of SBM was estimated to be between $105 \%$ and $125 \%$ of corn, which is much greater than the NRC (2012) would indicate.

Keywords: Caloric efficiency, Energy, Soybean meal, Swine

\section{Background}

Soybean meal (SBM) is the primary plant-protein source for swine diets in the United States. The amino acid (AA) profile of SBM is well-balanced and complements the AA profile of grains such as corn and wheat, and these AA are highly digestible for pigs [1]. The energy content of SBM has been reported [1] as $3619 \mathrm{kcal} / \mathrm{kg}$ digestible energy (DE) and $3294 \mathrm{kcal} / \mathrm{kg}$ metabolizable energy (ME), which suggests that SBM has 105\% and $97 \%$ of corn grain DE and ME values, respectively. More recently, swine nutritionists have adopted the net energy (NE) system due to the higher correlation to performance relative to DE or ME systems [2]. Using the NE system, SBM contains $2087 \mathrm{kcal} / \mathrm{kg}$, which is only $78 \%$ of the corn energy value [1]. However, recent research shows improvements in gain-to-feed ratio (G:F) of pigs fed increasing levels of SBM [3, 4], which could indicate that the NRC [1] underestimates the NE of SBM.

Calorimetry trials to measure $\mathrm{NE}$ involve laborintensive procedures that require highly specialized equipment. A practical approach conducted under field conditions to estimate energy values has gained acceptance among swine nutritionists. Feeding increasing amounts of an ingredient and using the differences in caloric efficiency (CE) to estimate the energy content of a test ingredient relative to a known ingredient, usually corn, has been reported by others and sometimes termed productive energy [5-9]. As the inclusion of the test ingredient increases, CE should not change if its energy estimate is accurate. Increases or decreases in $\mathrm{CE}$ indicate over- or underestimation of the energy content. Therefore, the objective of this study was to determine differences in growth performance of pigs fed increasing amounts of SBM and, by using changes in CE, to estimate SBM energy value relative to corn.

\section{Methods}

The Kansas State University Institutional Animal Care and Use Committee approved the protocol used in these experiments.

\section{Diets and experimental design}

Representative samples of corn grain, SBM, and distillers dried grains with solubles were submitted to the Agricultural Experimental Station Chemical Laboratories (University of Missouri-Columbia, Columbia, MO, USA) for determination of total AA content (method 982.30; AOAC International [10]) prior to diet formulation (Table 1) in Exp. 1. The total AA values were multiplied by NRC [1] standardized ileal digestible coefficients and used in diet formulation. Corn, SBM, and distillers dried grains were also analyzed (Ward Laboratories, Inc., Kearney, NE) for dry matter (method 935.29; AOAC

Table 1 Proximate analysis and total amino acid content of corn, distillers dried grains with solubles (DDGS), and soybean meal fed in Exp. 1, as-is basis ${ }^{a, b}$

\begin{tabular}{|c|c|c|c|}
\hline Item, $\%$ & Corn & DDGS & Soybean meal \\
\hline Dry matter & 87.8 & 90.8 & 88.8 \\
\hline Crude protein & 6.3 & 28.7 & 48.0 \\
\hline Neutral detergent fiber & 7.0 & 27.9 & 5.4 \\
\hline Ether extract & 3.6 & 8.8 & 1.1 \\
\hline Calcium & 0.07 & 0.08 & 0.42 \\
\hline Phosphorus & 0.23 & 0.88 & 0.64 \\
\hline \multicolumn{4}{|l|}{ Amino acids } \\
\hline Alanine & 0.45 & 1.86 & 2.06 \\
\hline Arginine & 0.30 & 1.27 & 3.42 \\
\hline Aspartic acid & 0.44 & 1.79 & 5.39 \\
\hline Cysteine & 0.16 & 0.60 & 0.73 \\
\hline Glutamic acid & 1.11 & 3.64 & 8.44 \\
\hline Glycine & 0.26 & 1.11 & 2.00 \\
\hline Histidine & 0.19 & 0.78 & 1.27 \\
\hline Isoleucine & 0.24 & 1.09 & 2.33 \\
\hline Leucine & 0.71 & 3.19 & 3.71 \\
\hline Lysine & 0.25 & 1.08 & 3.09 \\
\hline Methionine & 0.13 & 0.50 & 0.66 \\
\hline Phenylalanine & 0.31 & 1.69 & 2.52 \\
\hline Proline & 0.56 & 2.07 & 2.41 \\
\hline Serine & 0.29 & 1.26 & 1.91 \\
\hline Threonine & 0.23 & 1.10 & 1.81 \\
\hline Tryptophan & 0.06 & 0.22 & 0.73 \\
\hline Tyrosine & 0.18 & 1.03 & 1.66 \\
\hline Valine & 0.31 & 1.45 & 2.44 \\
\hline
\end{tabular}

${ }^{\mathrm{a} A}$ representative sample of each ingredient was obtained, homogenized, and submitted to the Agricultural Experimental Station Chemical Laboratories (University of Missouri-Columbia, Columbia, MO, USA) for amino acid analysis and Ward Laboratories (Kearney, NE) for proximate analysis prior to diet formulation

${ }^{\mathrm{b}}$ For Exp. 2, the NRC (2012) [1]amino acid values were used in diet formulation 
International [10]), crude protein (method 990.03; AOAC International [10]), neutral detergent fiber (Ankom [11]), and ether extract (Ankom [12]). For Exp. 2, diets were formulated using NRC [1] nutrient loadings.

There were 4 dietary treatments in Exp. 1 consisting of increasing amounts of SBM $(21 \%, 27 \%, 33 \%$, or $39 \%$ of the diet) with 23 replicates per treatment. In Exp. 2, there were 6 dietary treatments $(17.5 \%, 22.0 \%, 26.5 \%$, $31.0 \%, 35.5 \%$, or $40.0 \% \mathrm{SBM}$ ) with 14 replicates per treatment. The increasing amounts of SBM were obtained by changing the inclusion of feed-grade AA and corn grain (Tables 2 and 3). Diets were formulated to meet or exceed the NRC (2012) [1] requirement estimates and were not balanced for NE. The NRC [1] NE value for SBM $(2087 \mathrm{kcal} / \mathrm{kg})$ and corn $(2672 \mathrm{kcal} / \mathrm{kg})$ were used in diet formulation. The NE value for DDGS was estimated as a function of the oil content based on Graham et al. [7] equation. Diets were provided in mash form. The energy value of SBM relative to corn was estimated based on $\mathrm{CE}$, which was obtained by multiplying ADFI by kcal of NE per $\mathrm{kg}$ of diet and dividing by ADG. In order to obtain an energy estimate, the energy value of SBM was adjusted for the slope of CE to be zero.

\section{Animals and housing}

Experiment 1 was conducted at New Horizon Farms Nursery Research (Pipestone, MN). A total of 2233 pigs (PIC $337 \times 1050$, Hendersonville, TN) were placed in 92 pens containing 20 to 27 mixed gender pigs and used in a 21 -d trial. Each pen $(3.7 \mathrm{~m} \times 2.3 \mathrm{~m})$ had plastic floors and was equipped with a six-hole stainless steel dry feeder and a pan waterer. Experiment 2 was conducted at the JBS Research Facility (Tipton, MO, USA). A total of 3796 pigs (PIC $359 \times$ C40, Hendersonville, TN, USA) were placed in 84 pens with 37 to 43 pigs per pen. Each pen $(6.9 \mathrm{~m} \times 3.6 \mathrm{~m})$ had fully slated floors and was equipped with a 4-hole stainless steel wet-dry feeder and a nipple waterer.

Pigs were weaned at approximately $21 \mathrm{~d}$ of age, placed in pens based on initial body weight (BW), and fed common diets until the start of the experiments. Pens of pigs were blocked by BW (initial BW $=11.0 \mathrm{~kg}$ in Exp. 1 and $17.6 \mathrm{~kg}$ in Exp. 2, respectively) and allotted to 1 of 4 or 6 treatments in Exp. 1 and 2, respectively, in a randomized complete block design. Pens of pigs were weighed, and feed disappearance was measured weekly to determine average daily gain (ADG), average daily feed intake (ADFI), G:F, and CE. Culls and mortality were recorded daily.

\section{Chemical analysis}

Representative diet samples were obtained from each treatment and stored at $-20^{\circ} \mathrm{C}$ until analysis. Samples were analyzed for dry matter (method 935.29; AOAC International [10]), crude protein (method 990.03;
Table 2 Ingredient composition of experimental diets, Exp. 1, as-fed basis

\begin{tabular}{lllll}
\hline & \multicolumn{5}{l}{ Soybean meal, \% } \\
\cline { 2 - 5 } & 21 & 27 & 33 & 39 \\
\hline Ingredient, \% & & & & \\
Corn & 60.07 & 54.68 & 49.21 & 43.70 \\
Soybean meal & 21.00 & 27.00 & 33.00 & 39.00 \\
DDGS & 15.00 & 15.00 & 15.00 & 15.00 \\
Calcium carbonate & 1.08 & 1.08 & 1.08 & 1.08 \\
Monocalcium phosphate, 21.5\% P & 0.65 & 0.55 & 0.50 & 0.40 \\
Sodium chloride & 0.50 & 0.50 & 0.50 & 0.50 \\
L-Lys HCl & 0.643 & 0.456 & 0.255 & 0.053 \\
DL-Met & 0.225 & 0.170 & 0.110 & 0.045 \\
L-Thr & 0.295 & 0.215 & 0.135 & 0.040 \\
L-Trp & 0.095 & 0.060 & 0.020 & - \\
L-Val & 0.225 & 0.115 & - & - \\
L-lle & 0.040 & - & - & - \\
Vitamin trace-mineral premix ${ }^{\mathrm{a}}$ & 0.150 & 0.150 & 0.150 & 0.150 \\
Phytase & 0.050 & 0.050 & 0.050 & 0.050 \\
Total & 100 & 100 & 100 & 100
\end{tabular}

Calculated analysis

SID amino acids, \%

$$
\text { Lys }
$$

Ile:Lys

Leu:Lys

Met:Lys

Met+Cys:Lys

Thr:Lys

Trp:Lys

Val:Lys

His:Lys

Net energy ${ }^{c}, \mathrm{kcal} / \mathrm{kg}$

Crude protein, \%

Neutral detergent fiber, \%

Calcium, \%

STTD P, \%

Analyzed values, \%

$\begin{array}{lllll}\text { Dry matter } & 87.7 & 88.1 & 88.2 & 88.5 \\ \text { Crude protein } & 20.0 & 21.4 & 24.2 & 25.9 \\ \text { Neutral detergent fiber } & 9.2 & 9.8 & 9.8 & 9.3 \\ \text { Ether extract } & 2.9 & 3.0 & 2.8 & 2.6\end{array}$

aprovided per kg of premix: 5,344,543 IU vitamin A; 1,336,137 IU vitamin D; 100,211 IU vitamin $E_{;} ; 1,671 \mathrm{mg}$ vitamin $\mathrm{K} ; 21.4 \mathrm{mg}$ vitamin $\mathrm{B}_{12} ; 29,061 \mathrm{mg}$ niacin; $15,366 \mathrm{mg}$ pantothenic acid; $4,008 \mathrm{mg}$ riboflavin; $66.8 \mathrm{mg}$ biotin; 668 $\mathrm{mg}$ folic acid; $1,202 \mathrm{mg}$ vitamin $\mathrm{B}_{6} ; 73 \mathrm{~g} \mathrm{Zn}$ from zinc sulfate; $67 \mathrm{~g}$ Fe from ferrous sulfate; $27 \mathrm{~g} \mathrm{Mn}$ from manganese oxide; $10 \mathrm{~g} \mathrm{Cu}$ from copper sulfate; $0.5 \mathrm{~g}$ I from calcium iodate; $0.2 \mathrm{~g}$ Se from sodium selenite

${ }^{\mathrm{b}}$ Optiphos 2000 (Huvepharma, Inc., Peachtree City, GA, USA)

${ }^{c}$ Net energy values were obtained from the NRC (2012) [1] 
Table 3 Ingredient composition of experimental diets, Exp. 2, as-fed basis

\begin{tabular}{|c|c|c|c|c|c|c|}
\hline & \multicolumn{6}{|c|}{ Soybean meal, \% } \\
\hline & 17.5 & 22.0 & 26.5 & 31.0 & 35.5 & 40.0 \\
\hline \multicolumn{7}{|l|}{ Ingredient, \% } \\
\hline Corn & 62.69 & 58.78 & 54.86 & 50.90 & 46.98 & 43.07 \\
\hline Soybean meal & 17.50 & 21.99 & 26.48 & 31.01 & 35.5 & 40.00 \\
\hline DDGS & 15.00 & 15.00 & 15.00 & 15.00 & 15.00 & 15.00 \\
\hline Calcium carbonate & 1.35 & 1.36 & 1.36 & 1.37 & 1.37 & 1.37 \\
\hline Monocalcium phosphate, $21.5 \% \mathrm{P}$ & 0.46 & 0.37 & 0.28 & 0.19 & 0.09 & - \\
\hline Sodium chloride & 0.43 & 0.42 & 0.42 & 0.41 & 0.40 & 0.40 \\
\hline L-Lys sulfate & 1.694 & 1.355 & 1.016 & 0.678 & 0.339 & - \\
\hline Met hydroxy analog & 0.195 & 0.159 & 0.123 & 0.088 & 0.052 & 0.016 \\
\hline L-Thr & 0.247 & 0.198 & 0.148 & 0.099 & 0.050 & - \\
\hline L-Trp & 0.071 & 0.057 & 0.043 & 0.028 & 0.014 & - \\
\hline L-Val & 0.147 & 0.117 & 0.088 & 0.059 & 0.030 & - \\
\hline$L-\| l e$ & 0.061 & 0.049 & 0.037 & 0.024 & 0.012 & - \\
\hline Vitamin trace-mineral premix ${ }^{a}$ & 0.150 & 0.150 & 0.150 & 0.150 & 0.150 & 0.150 \\
\hline Total & 100 & 100 & 100 & 100 & 100 & 100 \\
\hline \multicolumn{7}{|l|}{ Calculated analysis } \\
\hline \multicolumn{7}{|l|}{ SID amino acids, $\%$} \\
\hline Lys & 1.20 & 1.20 & 1.20 & 1.20 & 1.20 & 1.20 \\
\hline Ile:Lys & 55 & 60 & 66 & 71 & 76 & 81 \\
\hline Leu:Lys & 124 & 133 & 142 & 151 & 160 & 169 \\
\hline Met:Lys & 37 & 36 & 35 & 34 & 33 & 32 \\
\hline Met+Cys:Lys & 58 & 59 & 59 & 60 & 61 & 62 \\
\hline Thr:Lys & 64 & 65 & 66 & 67 & 68 & 69 \\
\hline Trp:Lys & 19.2 & 20.1 & 21.0 & 21.8 & 22.7 & 23.5 \\
\hline Val:Lys & 70 & 74 & 77 & 81 & 85 & 88 \\
\hline His:Lys & 34 & 38 & 42 & 45 & 49 & 52 \\
\hline Net energy, kcal/kg & 2455 & 2433 & 2411 & 2388 & 2366 & 2344 \\
\hline Crude protein, \% & 18.9 & 20.5 & 22.1 & 23.7 & 25.3 & 26.9 \\
\hline Neutral detergent fiber, \% & 12.17 & 12.19 & 12.20 & 12.21 & 12.22 & 12.23 \\
\hline Calcium, \% & 0.69 & 0.69 & 0.69 & 0.69 & 0.69 & 0.69 \\
\hline STTD P, \% & 0.38 & 0.38 & 0.37 & 0.36 & 0.36 & 0.35 \\
\hline \multicolumn{7}{|l|}{ Analyzed values, \% } \\
\hline Dry matter & 85.7 & 86.0 & 85.9 & 86.2 & 86.9 & 86.8 \\
\hline Crude protein & 17.2 & 19.2 & 20.2 & 22.7 & 23.7 & 25.6 \\
\hline Crude fiber & 2.2 & 2.4 & 2.7 & 3.1 & 3.0 & 3.2 \\
\hline Ether extract & 3.1 & 3.1 & 3.1 & 3.1 & 3.3 & 3.3 \\
\hline
\end{tabular}

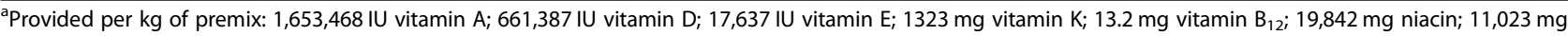
pantothenic acid; $3307 \mathrm{mg}$ riboflavin; 499,899 FTU phytase; $73 \mathrm{~g} \mathrm{Zn}$ from zinc sulfate; $67 \mathrm{~g}$ Fe from ferrous sulfate; $27 \mathrm{~g} \mathrm{Mn}$ from manganese oxide; $10 \mathrm{~g}$ Cu from copper sulfate; $0.5 \mathrm{~g}$ I from calcium iodate; $0.2 \mathrm{~g}$ Se from sodium selenite

AOAC International [10]), calcium (method 985.01; AOAC International [10]), phosphorus (method 985.01; AOAC International [10]), neutral detergent fiber (Ankom [11]), and ether extract (Ankom [12]).

\section{Statistical analysis}

Data were analyzed as a randomized complete block design with initial BW as the blocking factor. Single degree-of-freedom contrasts were constructed to test the 
linear and quadratic effects of increasing SBM. Block was included as a random effect and treatment as a fixed effect. Pen was considered the experimental unit. Data were analyzed using the GLIMMIX procedure of SAS 9.4 (SAS Institute Inc., Cary, NC, USA). Data distribution was assessed using visual inspection of histograms prior to statistical analysis. Results were considered significant at $P \leq 0.05$ and a tendency at $0.05<P \leq 0.10$.

\section{Results and discussion Chemical analysis}

The analyzed amino acid profiles of corn, DDGS, and SBM used in Exp. 1 were, in general, within the expected values (Table 1). Soybean meal and DDGS had a similar amino acid composition to NRC [1] values, whereas AA in corn were slightly lower than NRC [1] estimates, especially for Met and Leu. The chemical analysis of diets was consistent with formulated values (Tables 2 and 3).

\section{Growth performance and energy estimate}

In Exp. 1, there was a tendency (linear, $P=0.092$ ) for a decrease in ADFI as dietary SBM increased (Table 4). Pigs fed diets with increasing SBM had a tendency (quadratic, $P=0.090$ ) for an improvement in ADG up to $33 \%$ SBM, followed by a decrease in ADG when 39\% SBM was fed. The changes in ADG and ADFI resulted in a tendency (quadratic, $P=0.069$ ) for an improvement in G:F up to $33 \%$ SBM. There was an improvement (linear, $P=0.001$; quadratic, $P=0.063$ ) in $C E$ with increasing SBM. There was no evidence $(P>0.10)$ for difference in cull and mortality rate.

In Exp. 2, there was a reduction (linear, $P=0.001$ ) in ADFI as SBM increased. Pigs fed increasing SBM had a tendency (linear, $P=0.065$ ) for reduced ADG (Table 5). However, the differences were relatively small and did not result in differences $(P \geq 0.27)$ in final BW. There was an improvement (linear, $P=0.001$ ) in $\mathrm{G}: \mathrm{F}$ and $\mathrm{CE}$ as
SBM increased. There was a reduction (linear, $P=0.050$ ) in cull and mortality rate as SBM increased.

A considerable amount of research has been conducted to evaluate the effects of SBM on growth performance of pigs. It is well known that the addition of SBM should be restricted in the diet immediately after weaning due to a hypersensitivity reaction [13, 14], but the restriction is not necessary after initial exposure. Nevertheless, feeding SBM is usually limited due to the high cost compared to diets formulated with high amounts of feed-grade AA as a replacement of intact protein sources. However, some research suggests feeding diets with higher amounts of SBM could prove beneficial, especially for health challenged pigs. Johnston et al. [15] fed $21 \%$ or $32 \%$ SBM to grow-finish pigs that were infected with porcine reproductive and respiratory syndrome (PRRS) and observed that pigs fed 32\% SBM had improved ADG and G:F compared with those fed 21\% SBM. Similarly, Rocha et al. [16] observed improvements in G:F of nursery pigs inoculated with PRRS virus and fed 22.5\% SBM compared to $12.5 \%$ SBM. Rochell et al. [17] found that PRRS positive nursery pigs had improved ADG when fed 29\% SBM compared to $17.5 \%$ SBM. Conversely, Cemin et al. [4] fed $27 \%$ or $35 \%$ SBM to PRRS negative nursery pigs and observed improvements in ADG and G:F as SBM increased. Moran et al. [3] conducted two trials evaluating increasing amounts of SBM for nursery pigs. In the first trial, pigs were PRRS negative and the authors observed a consistent improvement in G:F. However, the results were not repeated in the subsequent study when pigs originated from a PRRS positive sow farm performance.

Interestingly, Moran et al. [3] found a reduction in the percentage of pigs removed for medical treatment from $11.1 \%$ to $8.4 \%$ as SBM increased. This observation is in agreement to our finding in Exp. 2, where increasing SBM linearly reduced cull rate. The benefits of SBM on growth performance, especially for health challenged

Table 4 Effects of increasing soybean meal inclusion on growth performance and caloric efficiency of pigs, Exp. $1^{\text {a }}$

\begin{tabular}{|c|c|c|c|c|c|c|c|}
\hline \multirow[b]{2}{*}{ Item } & \multicolumn{4}{|c|}{ Soybean meal, \% } & \multirow[t]{2}{*}{ SEM } & \multicolumn{2}{|c|}{ Probability, $P$} \\
\hline & 21 & 27 & 33 & 39 & & Linear & Quadratic \\
\hline \multicolumn{8}{|l|}{ BW, kg } \\
\hline d 0 & 11.0 & 11.0 & 11.0 & 11.0 & 0.15 & $<0.894$ & $<0.993$ \\
\hline d 21 & 22.3 & 22.3 & 22.4 & 22.0 & 0.28 & $<0.263$ & $<0.180$ \\
\hline \multicolumn{8}{|l|}{ d 0 to 21} \\
\hline$A D G, g$ & 537 & 537 & 543 & 524 & 7.3 & $<0.207$ & $<0.090$ \\
\hline$A D F I, g$ & 824 & 822 & 815 & 804 & 11.7 & $<0.092$ & $<0.579$ \\
\hline $\mathrm{G}: \mathrm{F}, \mathrm{g} / \mathrm{kg}$ & 652 & 653 & 667 & 653 & 5.1 & $<0.390$ & $<0.069$ \\
\hline CE, kcal/kg gain & 3801 & 3738 & 3600 & 3623 & 28.8 & $<0.001$ & $<0.063$ \\
\hline Culls and mortality, \% & 0.72 & 0.36 & 0.36 & 0.36 & 0.356 & $<0.457$ & $<0.596$ \\
\hline
\end{tabular}

${ }^{\mathrm{a}} \mathrm{A}$ total of 2233 pigs (initially $11.0 \mathrm{~kg}$ ) were used in a $21-\mathrm{d}$ study with 20 to 27 pigs per pen and 23 replicates per treatment 
Table 5 Effects of increasing soybean meal inclusion on growth performance and caloric efficiency of pigs, Exp. $2^{a}$

\begin{tabular}{|c|c|c|c|c|c|c|c|c|c|}
\hline \multirow[b]{2}{*}{ Item } & \multicolumn{6}{|c|}{ Soybean meal, \% } & \multirow[t]{2}{*}{ SEM } & \multicolumn{2}{|c|}{ Probability, $P$} \\
\hline & 17.5 & 22.0 & 26.5 & 31.0 & 35.5 & 40.0 & & Linear & Quadratic \\
\hline \multicolumn{10}{|l|}{ BW, kg } \\
\hline d 0 & 17.5 & 17.6 & 17.5 & 17.6 & 17.6 & 17.6 & 0.20 & $<0.801$ & $<0.997$ \\
\hline d 22 & 35.6 & 35.8 & 35.5 & 35.4 & 35.5 & 35.4 & 0.28 & $<0.272$ & $<0.987$ \\
\hline \multicolumn{10}{|l|}{ d 0 to 22} \\
\hline$A D G, g$ & 820 & 825 & 818 & 809 & 812 & 809 & 7.4 & $<0.065$ & $<0.922$ \\
\hline ADFI, g & 1500 & 1509 & 1473 & 1424 & 1415 & 1401 & 18.1 & $<0.001$ & $<0.957$ \\
\hline $\mathrm{G}: \mathrm{F}, \mathrm{g} / \mathrm{kg}$ & 547 & 548 & 556 & 568 & 574 & 578 & 5.4 & $<0.001$ & $<0.893$ \\
\hline CE, kcal/kg gain & 4491 & 4450 & 4342 & 4203 & 4126 & 4055 & 43.6 & $<0.001$ & $<0.955$ \\
\hline Culls and mortality, \% & 0.58 & 0.89 & 0.71 & 0.43 & 0.14 & 0.14 & 0.447 & $<0.050$ & $<0.377$ \\
\hline
\end{tabular}

${ }^{\mathrm{a}} \mathrm{A}$ total of 3796 pigs (initially $17.6 \mathrm{~kg}$ ) were used in a 22 -d study with 37 to 43 pigs per pen and 14 replicates per treatment

pigs, have also been hypothesized to be driven by bioactive components such as isoflavones and saponins, which have anti-inflammatory, antioxidant, and antiviral properties $[18,19]$. However, the available research is inconsistent regarding the effects of isoflavones on growth performance of pigs. Kuhn et al. [20] compared SBM and soy protein concentrate, an ingredient with markedly lower isoflavones relative to SBM, in a weanto-finish study and observed higher plasma isoflavones in pigs fed SBM but no evidence for differences in growth performance. Greiner et al. [21, 22] evaluated increasing dietary isoflavones and observed improvements in performance of PRRS positive pigs, mostly during periods of peak viremia. Smith et al. [19] fed diets based on soy protein concentrate or enzyme-treated SBM with or without isoflavones and observed changes in activation of the adaptive immune system, although no impact on growth performance was observed.

There was a tendency for a quadratic response in ADG with increasing SBM in Exp. 1, with a decrease observed in ADG of pigs fed the highest SBM inclusion. Similarly, in Exp. 2 there was a slight reduction in ADG with increasing SBM. However, the differences between treatments were relatively small and did not result in statistical differences in final BW. Feed intake was also negatively affected by high levels of SBM. The reason for the negative response of high SBM inclusion on ADFI and ADG is unclear. Although the available literature generally does not agree with this finding, as the majority of studies $[3,4,15-17]$ found no change or improvements in ADG with increasing SBM, the current experiment evaluated higher SBM levels than most of the previous research. It could be hypothesized that the high level of crude protein in the diet with 39\% SBM provided excess nitrogen which needs to be metabolized and excreted by the animal [23]. The excess nitrogen represents an energy cost that may ultimately translate to decreased growth performance. Moreover, the Leu:
Lys increased with increasing levels of SBM. It is well known that excessive Leu leads to reduction in feed intake [24]; however, recent research suggests that the negative impact may be counteracted by concomitant increases in Ile, Val, and Trp [25], as observed in our experimental diets.

Improvements in feed efficiency with increasing amounts of SBM seem to be more consistently reported in the literature and agree with our findings. Energy is the most expensive component of any swine diet, thus it is critical to accurately determine the energy value of feedstuffs. Direct measurement of NE is a procedure that requires highly specialized equipment. Therefore, the estimation of the energy value of a test ingredient based on $\mathrm{CE}$ relative to a known ingredient such as corn grain is suggested as a practical approach, and is sometimes termed productive energy [5-9]. Besides the practical advantage, the estimates using $\mathrm{CE}$ conducted under field conditions may be more predictive of growth performance than other energy values. The diets used in our experiments were formulated using the NRC [1] NE value for SBM and were not balanced for energy; thus, as SBM increased, dietary NE decreased. The resulting dietary $\mathrm{NE}$ values ranged from 2475 to $2362 \mathrm{kcal} / \mathrm{kg}$ in Exp. 1 and 2455 to $2344 \mathrm{kcal} / \mathrm{kg}$ in Exp. 2. Therefore, if the NE of SBM provided by the NRC [1] was accurate, G:F should become worse as SBM level increased in the diet. However, the improvement in $\mathrm{CE}$ observed in the current experiments suggest that the NE value of SBM was underestimated. The NRC [1] NE value for SBM is $2087 \mathrm{kcal} / \mathrm{kg}$ or $78 \%$ of corn NE. Our findings from Exp. 1 based on CE suggest that the energy value of SBM is $105.4 \%$ of corn grain energy or $2816 \mathrm{kcal} / \mathrm{kg}$ NE. It is important to note that, while $C E$ response was significantly linear $(P=0.001)$, there was also a tendency $(P=0.065)$ for a quadratic response. Therefore, it could be hypothesized that the CE value of 39\% SBM treatment should not be considered for estimating energy because slope- 
ratio assays should only include the linear portion of the response [26]. By removing the 39\% SBM diet and using the linear portion of the dataset results in an energy estimate of $121.1 \%$ of corn grain energy or $3236 \mathrm{kcal} / \mathrm{kg}$ NE. A similar response was observed in Exp. 2, where energy value of SBM was estimated as $124.7 \%$ of corn grain energy or $3332 \mathrm{kcal} / \mathrm{kg}$. The energy estimates of both experiments are greater than the NRC [1] NE value, which may be driven by Noblet et al. [27] equations too severely penalizing the NE content of high crude protein ingredients. However, it is important to note the using $\mathrm{CE}$ to estimate the energy value of an ingredient as a ratio to corn has limitations. This approach assumes that the NE values of corn are accurate and does not account for changes in body composition, which can influence the CE response as leaner pigs are more efficient [28]. Using indirect calorimetry, Li et al. [29] found that a NE of $2709 \mathrm{kcal} / \mathrm{kg}$ for SBM, which is $101.4 \%$ of NRC [1] corn NE and significantly greater than the NRC [1] SBM NE value.

Another important consideration is that the responses in performance could have been driven by underestimation of the AA requirements relative to Lys. Our diets were formulated to meet or exceed the NRC [1] requirement estimates; nevertheless, if any of these estimates is not accurate, by increasing the inclusion of SBM we could have potentially corrected an AA deficiency. However, most of the AA ratios were well above that recommended by the NRC [1], thus the responses to SBM are unlikely to be driven by changes in AA ratios.

\section{Conclusion}

Nursery pigs fed diets with increasing amounts of SBM presented inconsistent responses in ADG, but G:F and $\mathrm{CE}$ were improved in both experiments. The results of the current study suggest that the energy value of SBM may be estimated to range between $105 \%$ and $125 \%$ of corn energy, or 2816 and $3332 \mathrm{kcal} / \mathrm{kg} \mathrm{NE}$, which indicates that the NRC [1] potentially underestimates the SBM NE value. This has important ramifications as it increases the value of SBM in diet formulation. However, it is unclear if the benefit of higher inclusion of SBM is entirely driven by energy or if another underlying mechanism, potentially involving intrinsic SBM components such as isoflavones, could be partially responsible for the response observed in this study.

\section{Abbreviations}

AA: Amino acid; ADFI: Average daily feed intake; ADG: Average daily gain; BW: Body weight; CE: Caloric efficiency; DDGS: Distillers dried grains with solubles; DE: Digestible energy; G:F: Gain-to-feed ratio; ME: Metabolizable energy; NE: Net energy; PRRS: Porcine reproductive and respiratory syndrome; SBM: Soybean meal; SID: Standardized ileal digestible; STTD: Standardized total tract digestible

\section{Acknowledgements}

Contribution no. 19-315-J from the Kansas Agricultural Experiment Station. Appreciation is expressed to New Horizon Farms (Pipestone, MN) and JBS USA (Greeley, CO) for technical support and expertise in conducting the experiments.

\section{Authors' contributions}

All authors read and approved the final manuscript.

\section{Funding}

Financial support for this research from United Soybean Board, Chesterfield, MO, USA.

\section{Availability of data and materials}

Data availability upon request to the corresponding author.

Ethics approval and consent to participate

Not applicable.

Consent for publication

Not applicable.

\section{Competing interests}

The authors declare that they have no competing interests

\section{Author details}

${ }^{1}$ Department of Animal Sciences and Industry, College of Agriculture, Kansas State University, Manhattan, KS 66506, USA. ${ }^{2}$ Department of Diagnostic Medicine/Pathobiology, College of Veterinary Medicine, Kansas State University, Manhattan, KS 66506, USA. ${ }^{3}$ JBS USA, Greeley, CO 80634, USA.

Received: 3 February 2020 Accepted: 17 May 2020

Published online: 03 July 2020

\section{References}

1. NRC. Nutrient requirements of swine. 11th ed. Washington: Natl. Acad. Press; 2012.

2. Nitikanchana S, Dritz SS, Tokach MD, DeRouchey JM, Goodband RD, White BJ. Regression analysis to predict growth performance from dietary net energy in growing-finishing pigs. J Anim Sci. 2015;93:2826-39.

3. Moran K, Boyd RD, Zier-Rush C, Wilcock P, Bajjalieh N, van Heugten E. Effects of high inclusion of soybean meal and a phytase superdose on growth performance of weaned pigs housed under the rigors of commercial conditions. J Anim Sci. 2017;95:5455-65.

4. Cemin HS, Tokach MD, Gaines AM, Ratliff BW, Dritz SS, Woodworth JC, et al. Effects of soybean meal level and distillers dried grains inclusion on growth performance of late nursery pigs. J Anim Sci. 2019;97(ESuppl. 2):88-9 (Abstr.).

5. Boyd RD, Zier-Rush CE, Fralick CE. Practical method for estimating productive energy (NE) of wheat midds for growing pigs. J Anim Sci. 2010; 88(E-Suppl. 3):153 (Abstr.).

6. Boyd RD, Zier-Rush CE, Fralick CE. Practical method for productive energy $(\mathrm{NEm}+\mathrm{g})$ estimation of soybean meal for growing pigs. J Anim Sci. 2011; 89(E-Suppl. 2):89 (Abstr.).

7. Graham AB, Goodband RD, Tokach MD, Dritz SS, DeRouchey JM, Nitikanchana S, et al. The effects of low-, medium-, and high-oil distillers dried grains with solubles on growth performance, nutrient digestibility, and fat quality in finishing pigs. J Anim Sci. 2014;92:3610-23.

8. Gonçalves MAD, Dritz SS, Jones CK, Tokach MD, DeRouchey JM, Woodworth JC, et al. Fact sheets - ingredient database management: part I, overview and sampling procedures and part II, energy. J Swine Health Prod. 2016;24:216-21.

9. Estrada JE, Ellis M, Mendoza OF, Gaines AM. Estimation of the productive energy content of corn germ meal based on a growth assay in wean-tofinish pigs. J Anim Sci. 2017;95:(E Suppl. 2):95. (Abstr.).

10. AOAC International. Official methods of analysis AOAC international. 17th ed. Gaithersburg: AOAC Int; 2006.

11. Ankom Technology. Method for Determining Neutral Detergent Fiber, Ankom 200/220 Fiber Analyzer. Fairport: Ankom Technology; 1998. 
12. Ankom Technology. Rapid Determination of Oil/Fat Utilizing High Temperature Solvent Extraction. ANKOM XT20 Fat Analyzer. Fairport: Ankom Technology; 2004.

13. Li DF, Nelssen JL, Reddy PG, Blecha F, Hancock JD, Allee GL, et al. Transient hypersensitivity to soybean meal in the early weaned pig. J Anim Sci. 1990; 68:1790-9.

14. Engle MJ. The role of soybean meal hypersensitivity in postweaning lag and diarrhea in piglets. J Swine Health Prod. 1994;2:7-10.

15. Johnston ME, Boyd RD, Zier-Rush C, Fralick CE. Soybean meal level modifies the impact of high immune stress on growth and feed efficiency in pigs. J Anim Sci. 2010;88(E-Suppl. 3):57-8 (Abstr.).

16. Rocha GC, Boyd RD, Almeida JAS, Liu Y, Che TM, Dilger RN, et al. Soybean meal level in diets for pigs challenged with porcine reproductive and respiratory syndrome (PRRS) virus. J Anim Sci. 2013;2(E-Suppl. 2):31 (Abstr.).

17. Rochell SJ, Alexander LS, Rocha GC, Van Alstine WG, Boyd RD, Pettigrew JE, et al. Effects of dietary soybean meal concentration on growth and immune response of pigs infected with porcine reproductive and respiratory syndrome virus. J Anim Sci. 2015;93:2987-97.

18. Smith BN, Dilger RN. Immunomodulatory potential of dietary soybeanderived isoflavones and saponins in pigs. J Anim Sci. 2018;96:1288-304.

19. Smith BN, Morris A, Oelschlager ML, Connor J, Dilger RN. Effects of dietary soy isoflavones and soy protein source on response of weanling pigs to porcine reproductive and respiratory syndrome viral infection. J Anim Sci. 2019;97:2989-3006.

20. Kuhn G, Hennig U, Kalbe C, Rehfeldt C, Ren MQ, Moors S, et al. Growth performance, carcass characteristics and bioavailability of isoflavones in pigs fed soybean based diets. Arch Anim Nutr. 2004:58:265-76.

21. Greiner LL, Stahly TS, Stable TJ. The effect of dietary soy daidzein on pig growth and viral replication during a viral challenge. J Anim Sci. 2001;79: 3113-9.

22. Greiner LL, Stahly TS, Stable TJ. The effect of dietary soy genistein on pig growth and viral replication during a viral challenge. J Anim Sci. 2001;79: $1272-9$.

23. Van Milgen J, Dourmad JY. Concept and application of ideal protein for pigs. J Anim Sci Biotechnol. 2015;6:15.

24. Harper AE, Miller RH, Block KP. Branched-chain amino acid metabolism. Annu Rev Nutr. 1984:4:409-54.

25. Cemin HS, Tokach MD, Dritz SS, Woodworth JC, DeRouchey JM, Goodband $\mathrm{RD}$. Meta-regression analysis to predict the influence of branched-chain and large neutral amino acids on growth performance of pigs. J Anim Sci. 2019; 97:2505-14.

26. Littell RC, Henry PR, Lewis AJ, Ammerman CB. Estimation of relative bioavailability of nutrients using SAS procedures. J Anim Sci. 1997;75: 2672-83.

27. Noblet J, Fortune H, Shi XS, Dubois S. Prediction of net energy value of feeds for growing pigs. J Anim Sci. 1994;72:344-54.

28. Campbell RG, Taverner MR. Genotype and sex effects on the relationship between energy intake and protein deposition in growing pigs. J Anim Sci. 1988;66:676-86.

29. Li Z, Li Y, Lv Z, Liu H, Zhao J, Noblet J, et al. Net energy of corn, soybean meal and rapeseed meal in growing pigs. J Anim Sci Biotechn. 2017;8:44.

Ready to submit your research? Choose BMC and benefit from:

- fast, convenient online submission

- thorough peer review by experienced researchers in your field

- rapid publication on acceptance

- support for research data, including large and complex data types

- gold Open Access which fosters wider collaboration and increased citations

- maximum visibility for your research: over $100 \mathrm{M}$ website views per year

At BMC, research is always in progress.

Learn more biomedcentral.com/submissions 